\title{
Interactive effects of near-future temperature increase and ocean acidification on physiology and gonad development in adult Pacific sea urchin, Echinometra sp. $A$
}

\author{
S. Uthicke $\cdot$ M. Liddy $\cdot$ H. D. Nguyen $\cdot$ \\ M. Byrne
}

Received: 31 August 2013/Accepted: 5 May 2014/Published online: 20 May 2014

(C) The Author(s) 2014. This article is published with open access at Springerlink.com

\begin{abstract}
Increased atmospheric $\mathrm{CO}_{2}$ will have a twofold impact on future marine ecosystems, increasing global sea surface temperatures and uptake of $\mathrm{CO}_{2}$ (Ocean Acidification). Many experiments focus on the investigation of one of these stressors, but under realistic future climate predictions, these stressors may have interactive effects on individuals. Here, we investigate the effect of warming and acidification in combination. We test for interactive effects of potential near-future $(2100)$ temperature $\left(+2\right.$ to $\left.3{ }^{\circ} \mathrm{C}\right)$ and $p \mathrm{CO}_{2}(\sim 860-940 \mu \mathrm{Atm})$ levels on the physiology of the tropical echinoid Echinometra sp. A. The greatest reduction in growth was under simultaneous temperature and $\mathrm{pH} / p \mathrm{pO}_{2}$ stress (marginally significant temperature $\times \mathrm{pH} / p \mathrm{CO}_{2}$ interaction). This was mirrored by the physiological data, with highest metabolic activity (measured as respiration and ammonium excretion) occurring at the increased temperature and $p \mathrm{CO}_{2}$ treatment, although this was not significant for excretion. The perivisceral coelomic fluid $\mathrm{pH}$ was $\sim 7.5-7.6$, as typical for echinoids,
\end{abstract}

Communicated by Biology Editor Dr. Anastazia Banaszak

Electronic supplementary material The online version of this article (doi:10.1007/s00338-014-1165-y) contains supplementary material, which is available to authorized users.

S. Uthicke $(\bowtie) \cdot$ M. Liddy

Australian Institute of Marine Science, PMB No 3, Townsville, QLD 4810, Australia

e-mail: S.Uthicke@aims.gov.au

H. D. Nguyen · M. Byrne

Schools of Biomedical and Biological Sciences, University of Sydney, Sydney, NSW, Australia

H. D. Nguyen - M. Byrne

School of Medical Sciences, F13, University of Sydney, Sydney, NSW 2006, Australia and showed no significant changes between treatments. Indicative of active calcification, internal magnesium and calcium concentrations were reduced compared to the external medium, but were not different between treatments. Gonad weight was lower at the higher temperature, and this difference was more distinct and statistically significant for males. The condition of the gonads assessed by histology declined in increased temperature and low $\mathrm{pH}$ treatments. The Echinometra grew in all treatments indicating active calcification of their magnesium calcite tests even as carbonate mineral saturation decreased. Our results indicate that the interactive temperature and $\mathrm{pH}$ effects are more important for adult echinoids than individual stressors. Although adult specimens grow and survive in nearfuture conditions, higher energy demands may influence gonad development and thus population maintenance.

Keywords Climate change - Ocean acidification . Invertebrate physiology $\cdot$ Echinoderms $\cdot$ Reproduction

\section{Introduction}

Burning of fossil fuels has increased $\mathrm{CO}_{2}$ concentrations in the atmosphere by nearly $70 \%$ compared to pre-industrial levels. Increased carbon dioxide is predicted to increase global average temperature by $1.5-4.5^{\circ} \mathrm{C}$ towards the end of this century (depending on representative concentration pathways, RCPs; Meinshausen et al. 2011). Average sea water temperatures are predicted to follow this trend with best estimates for global sea surface temperature (SST) increase in the range of $1^{\circ}-3^{\circ}$ (Collins et al. 2013). Although extensive variation of SST increase is expected for different geographic regions (Brierley and Kingsford 2009), estimates for the Great Barrier Reef are well within 
this range (Hobday and Lough 2011). Over $30 \%$ of the $\mathrm{CO}_{2}$ emitted is absorbed by the world's ocean (Sabine et al. 2004). The increased partial pressure of $\mathrm{CO}_{2}$ leads to higher dissolved inorganic carbon, low calcium saturation states, and reduced ocean $\mathrm{pH}$ (i.e., ocean acidification, $\mathrm{OA})$. Depending on models and measures taken to reduce carbon emissions, $p \mathrm{CO}_{2}$, values between 420 and $>1,370$ are expected by the end of this century (Moss et al. 2010; Meinshausen et al. 2011). Ocean $\mathrm{pH}$ has already been reduced by 0.1 units compared to pre-industrial levels and is expected to further decrease by $0.3-0.5$ units towards the end of this century (Caldeira and Wickett 2005). Thus, marine flora and fauna face a twofold challenge in the near future needing to adapt to higher temperatures and decreased $\mathrm{pH} /$ increased $p \mathrm{CO}_{2}$.

Both elevated temperatures and low $\mathrm{pH} /$ hypercapnia can be stressors for marine invertebrate developmental stages, juveniles, and adults (Nguyen et al. 2009; Ries et al. 2009; Byrne 2011, 2012; Byrne and Przeslawski 2013).

Increased temperature may be stressful for marine invertebrates, especially tropical species many of which already live at the upper thermal limit of marine isotherms (Hoegh-Guldberg 1999). Ocean acidification is considered to be particularly deleterious for calcifying invertebrates, because calcification may be impaired by the associated reduction in carbonate mineral saturation (Doney et al. 2009). However, as $\mathrm{pH}, p \mathrm{CO}_{2}$, and mineral saturation are co-varying stressors, it is difficult to understand which of these are most important (Byrne et al. 2013). For echinoderms, which transport bicarbonate (not carbonate) at the site of calcification and use respiratory $\mathrm{CO}_{2}$ as a source of inorganic carbon (Sikes et al. 1981; Stumpp et al. 2012a), hypercapnia $\left(p \mathrm{CO}_{2}\right)$, not mineral saturation, appears to be the most important stressor. In addition, a recent synthesis of data on the response of calcification in echinoplutei across world climatic regions to ocean acidification conditions also indicated that hypercapnia was the more important stressor, although tropical species were more sensitive to decreased mineral saturation (Byrne et al. 2013). Recent transcriptomic analyses of echinoplutei reared under ocean acidification conditions indicate a change in biomineralisation, calcium and ion transport, and metabolic genes (Evans et al. 2013).

Although ocean warming and acidification will most likely occur in combination unless carbon emissions are drastically reduced, the interactive effects of these to stressors are poorly understood (Byrne and Przeslawski 2013). In tropical corals, calcification rates were reduced most under increased temperature and elevated $p \mathrm{CO}_{2}$ conditions (Reynaud et al. 2003). Similarly, juvenile stages of corals were most affected by a combination of temperature and $p \mathrm{CO}_{2}$ increase (Anlauf et al. 2011). In adult corals, increased $p \mathrm{CO}_{2}$ can reduce vulnerability to temperature stress such as bleaching (Anthony et al. 2008). In echinoid larvae, increased temperature and acidification act as additive stressors on growth in some species while in others, moderate warming reduces the negative effect of acidification on growth (Sheppard Brennand et al. 2010; Byrne et al. 2011, 2013). For adult asteroids (Parvulastrea exigua), temperature was shown to have a stronger effect compared to hypercapnia, but increased metabolism at higher temperatures was reduced under simultaneous $\mathrm{pH}$ stress (McElroy et al. 2012). Similarly, temperatureaffected metabolism of ophiuroids and a reduction in metabolism at intermediate $p \mathrm{CO}_{2}$ were observed at two separate temperatures (Christensen et al. 2011). The temperate ophiuroid Ophiura ophiura and the echinoid Paracentrotus lividus both showed an effect of $\mathrm{pH}$ on metabolism under low water temperature, but not under high temperature (Wood et al. 2010; Catarino et al. 2012). Combined temperature and $\mathrm{pH}$ stress showed no interaction in several response parameters in the polar ophiuroid Ophiocten sericeum, but arm regeneration in an extreme $\mathrm{pH}$ treatment $(\mathrm{pH}$ 7.3) was hampered under increased temperatures (Wood et al. 2011). The only study investigating interactive effects of temperature and $p \mathrm{CO}_{2}$ in tropical adult echinoids found that increased $p \mathrm{CO}_{2}$ decreased calcification in Echinometra lacunter more in winter than in summer (Courtney et al. 2013).

We investigated the physiological response of the adult rock-boring Indo-Pacific sea urchin Echinometra sp. $A$ in animals acclimated for approximately 10 weeks to nearfuture OA conditions $(\sim 860-940 \mu \mathrm{ATM})$ and temperature increase $\left(+2^{\circ}\right.$ to $3^{\circ}$ above present summer average). Echinometra sp. $A$ is one of the most abundant tropical sea urchin species in shallow reef areas where it can assume densities of 100 individuals $\mathrm{m}^{-2}$ (McClanahan and Muthiga 2007). This species is ecologically important because it can control algal growth, and high densities can prevent recovery of fish and coral populations after disturbance (McClanahan et al. 1996). In addition, feeding-driven bioerosion by Echinometra species removes carbonate (Downing and El-Zahr 1987; Carreiro-Silva and McClanahan 2001) which can reduce net accretion on coral reefs. Resulting burrows are often highly visible in the upper reef margins, and the species is thus habitat forming (McClanahan and Muthiga 2007). Growth of small adult $E$. mathaei was significantly reduced with only a small increase of $p \mathrm{CO}_{2}(220 \mu \mathrm{atm}, \mathrm{pH} 7.9$; Shirayama and Thornton 2005). Similarly, growth of larger adult Echinometra $\mathrm{sp}$. A was slightly reduced over a 7-week period under increased $p \mathrm{CO}_{2}$ (Uthicke et al. 2013). However, echinoids (including Echinometra spp.) at a tropical $\mathrm{CO}_{2}$ vent exhibited no decrease in abundance with decreased $\mathrm{pH} /$ increased $p \mathrm{CO}_{2}$ (Fabricius et al. 2014). As characteristic of echinoid echinoplutei (Byrne et al. 2013), increased 
$p \mathrm{CO}_{2}$ reduces larval growth and increases abnormal development in larval and adult Echinometra spp. (Kurihara and Shirayama 2004; Uthicke et al. 2013).

Only limited work has been conducted on a temperature effect on Echinometra spp. Its wide tropical Indo-Pacific distribution suggests a large temperature tolerance, and it can be found in locations with water temperature variations between 15 and $31{ }^{\circ} \mathrm{C}$ (summarised in Muthiga and Jaccarini 2005). However, given its shallow-water habitat, it can be assumed that E. mathaei can withstand extreme temperatures for a short period. Adult mortality of this species has been observed at $\sim 40{ }^{\circ} \mathrm{C}$ (Tsuchiya et al. 1987). Echinometra mathaei can still achieve high fertilisation rates at $36{ }^{\circ} \mathrm{C}$, but embryos only develop normally below $34{ }^{\circ} \mathrm{C}$ (Rupp 1973). Healthy development to early larval stages occurs between 19 and $31{ }^{\circ} \mathrm{C}$ (Rahman et al. 2007).

The main aim of this study was to test the hypothesis that a combined physiological effect of increased $p \mathrm{CO}_{2}$ and temperature is larger than that of each stressor individually. As response parameters, we measured overall growth, respiration, and ammonium excretion of Echinometra sp. A after $>70 \mathrm{~d}$ of exposure to the respective treatment conditions. In addition, we compared gonad development amongst the treatments and tested for differences in $\mathrm{pH}$ and ionic composition of the perivisceral coelomic fluid.

\section{Materials and methods}

Specimen collection and experimental set-up

Adult Echinometra sp. A (32-54 mm diameter, 16-68 g wet weight) were collected in September 2011 at 2-5 m water depth at Rib Reef, a midshelf reef in the central section of the Great Barrier Reef ( $\left.146^{\circ} 52.49^{\prime} \mathrm{E}, 18^{\circ} 28.86^{\prime} \mathrm{S}\right)$.

Taxonomic confusion exists about the genus Echinometra in the West Pacific Ocean with four species being described (Arakaki et al. 1998). Mitochondrial DNA sequencing of eight individuals from this experiment revealed that the population on Rib Reef belongs to Echinometra sp. A (Landry et al. 2003; GenBank Accession number: KF555645KF555652). This also applies to individuals from a previous experiment (Uthicke et al. 2013). The size range used represents 'intermediate-sized' adult animals at Rib Reef, omitting the smallest and largest specimens.

Sea urchins were placed into the aquaria on the 21 September 2011 (=Day 0) and kept under similar conditions with $p \mathrm{CO}_{2}$ manipulated as described in Uthicke et al. (2013). In short, urchins were fed ad libitum on brown macroalgae (Sargassum spp., Dictyota sp.) and coral rubble encrusted with crustose coralline algae was offered as an additional food source. The experiment was set up in a temperature-controlled $\left(25 \pm 1{ }^{\circ} \mathrm{C}\right)$ aquarium room. The aquarium water was filtered through three bag filters (WATERCO, Australia) in series $(25,10,5 \mu \mathrm{m})$.

An AquaMedic (Germany) $\mathrm{CO}_{2}$ dosing system was used to manipulate $p \mathrm{CO}_{2}$ levels. One $\mathrm{pH}$ probe (Aqua Medic, accuracy $0.01 \mathrm{pH}$ units) connected to the control system was placed into each of the four header tanks. The two treatments with increased $p \mathrm{CO}_{2}$ concentrations were set to $\mathrm{pH}_{\mathrm{NBS}} 7.90 \pm 0.05$. This value was chosen to represent $p \mathrm{CO}_{2}$ concentrations likely around the end of this century (RCP 6: 670 ppm, RCP 8.5: 963 ppm; Meinshausen et al. 2011) unless drastic measures such as carbon capture leading to net-carbon reductions are implemented (Arora et al. 2011). Solenoid valves were connected to a standard $\mathrm{CO}_{2}$ cylinder (GE 082, BOC, Australia) with a flow regulator. When the valves opened, $\mathrm{CO}_{2}$ gas was introduced into the header tanks through gas diffuser (AquaMedic).

Temperature in the header tanks was controlled using 4-kW titanium heating bars controlled by a CR 1,000 (Campell Scientific, Australia) control data logger. In the experiment, temperatures were set to $28^{\circ} \mathrm{C}$, the nearaverage recent summer maximum SST averaged over the warmest months, calculated as $28.71, \mathrm{SD}=0.40$, which was determined from the Davies Reef monitoring site (as above) for the 'present-day' scenario and $31{ }^{\circ} \mathrm{C}$ for the near-future scenario $\left(+2\right.$ to $\left.+3{ }^{\circ} \mathrm{C}\right)$.

To document potential variation between aquaria temperature and $\mathrm{pH}$ (using a temperature-corrected $\mathrm{pH}$ meter, OAKTON, USA; pH probe, EUTECH, USA), these were measured manually on most days $(N=55)$ throughout the experiment.

To confirm target levels and for calculation of $p \mathrm{CO} 2$ and saturation states, samples for dissolved inorganic carbon (DIC) and total alkalinity (TA) analyses were taken 4-6 times from each individual aquarium throughout the experiment. These samples were fixed with $125 \mu \mathrm{L}$ of saturated $(7 \mathrm{~g}$ in $100 \mathrm{~mL})$ mercuric chloride and analysed using a VINDTA 3C titrator (Marianda, Germany). Alkalinity was analysed by acid titration (Dickson et al. 2007) and DIC by acidification and coulometric $\mathrm{CO}_{2}$ detection (UIC 5105 Coulometer). Calibration was conducted using certified reference seawater (A. G. Dickson, Scripps Institute of Oceanography, Dixon, Batch 106). To describe natural variation of carbon chemistry parameters, samples from two locations with Echinometra sp. A populations were collected several times during different tide levels. The first of these populations was the source population at the backreef of Rib Reef. The second population was on a shallow reef flat on One Tree Island $\left(152^{\circ} 05.66^{\prime} \mathrm{E}, 23^{\circ}\right.$ $30.47^{\prime} \mathrm{S}$ ) in the southern GBR. These samples were fixed and analysed for TA and DIC as described above. 
Water from each of the four header tanks was pumped into three 16-L glass treatment aquaria (randomly allocated along the bench space). The flow to each aquarium was regulated via a flow controller set to $450-500 \mathrm{~mL} \mathrm{~min}^{-1}$. Water flow within each treatment aquarium was enhanced with a small submersible aquarium pump. Each replicate aquarium contained six specimens of Echinometra sp. A.

Light was supplied through 50:50 actinic 420-nm, 10-K trichromatic daylight (Catalina Compact, 12-h dark : 12-h light cycle, similar to field conditions) at 180-200 $\mu \mathrm{mol}$ photons $\mathrm{m}^{-2} \mathrm{~s}^{-1}$.

\section{Physiological parameters}

Initial wet weight after blotting $( \pm 0.1 \mathrm{~g})$ of the urchins was taken on day 1; final weights were taken on the 2 nd of December 2011. Thus, growth was measured over $70 \mathrm{~d}$ and expressed as the percentage increase of the original weight. To reduce the influence of gut contents on weight, measurements were taken after a $24-\mathrm{h}$ starvation period. The six individuals in each aquarium were distinguishable based on colour patterns and size, which allowed us to calculate individual growth rates.

Respiration rates of individual urchins were measured on day 69 in 15 specimens from each treatment. Respiration was measured in a respirometer that used an OXY-4 (Presens, Germany) fibre-optic oxygen meter to measure oxygen concentration in Perspex chambers (Uthicke et al. 2013). Temperature was set to the treatment temperature and controlled in a water bath (volume: $6.8 \mathrm{~L}$ ) connected to the pump of a temperature control $\left( \pm 0.1^{\circ} \mathrm{C}\right)$ unit (Lauda, Germany). Optodes inside the chambers were calibrated at the beginning and the end of the measurements using water-saturated air $\left(100 \% \mathrm{O}_{2}\right)$ and water treated with $\mathrm{Na}_{2} \mathrm{SO}_{4}\left(\begin{array}{lll}0 & \% & \mathrm{O}_{2}\end{array}\right)$. Individual Echinometra sp. $A$ were placed into a jar $(640 \mathrm{~mL})$ containing the respective treatment water and re-filtered using a $0.5-\mu \mathrm{m}$ cartridge filter. Specimens were incubated for a minimum of $25 \mathrm{~min}$ to allow for an initial period to stabilise temperatures and for individuals to settle. Oxygen saturation never went below $70 \%$, and a straight slope of the regression line indicated that these levels did not exert stress on the organisms. Blank chambers were run every two runs, but no background respiration was detectable. Respiration rates were calculated from slopes of oxygen concentration over time during the last $15 \mathrm{~min}$ of the incubations.

Ammonium excretion of 12 specimens of Echinometra sp. $A$ for each treatment was determined at day 75 during incubations in 500-mL glass jars. Incubation jars were immersed in a flow-through water bath to keep the temperature constant at the treatment temperatures. Similar to the respiration experiments, we used re-filtered $(0.5 \mu \mathrm{m})$ treatment water for the excretion incubations. Echinoderms can release high amounts of ammonium in the first few minutes of excretion experiments (Uthicke 2001). Therefore, duplicate initial water samples were collected from each incubation jar after a settle period of $\sim 10 \mathrm{~min}$. Subsequently, the jars were closed and duplicate final samples taken at approximately $60 \mathrm{~min}$ (53-64 min). Ammonium determination was conducted on an autoanalyser and followed methods as outlined in Ryle et al. (1981). Each specimen was weighed and ammonium excretion rates calculated taking into account actual water volume during incubations (initial volume minus the initial samples and urchin volume). Urchin volume was derived from wet weights using conversions as described in Uthicke et al. (2013).

Oxygen:nitrogen $(\mathrm{O}: \mathrm{N})$ ratios were calculated based on the ammonium excretion rates and average oxygen consumption for each treatment combination.

Gonad index and condition, and coelomic fluid composition

At the end of the experiment (07 December 2011, day 77), all Echinometra sp. A were dissected and the coelomic fluid carefully drained. One gonad was placed in Bouin's fluid for histology, and the other four with remaining tests and organs were oven-dried for $48 \mathrm{~h}$ at $60{ }^{\circ} \mathrm{C}$. Dried weight was used in preference to the wet gonad index more commonly used for sea urchins because there can be large inter-individual differences in fluid retention in the gonads. The fixed gonads were processed for routine wax histology, and the gonad sections ( $7 \mu \mathrm{m}$ thick) were stained in haematoxylin and eosin. Gonad histological condition was determined by microscopic examination of the sections. The gametogenic state of the gonads was scored in three stages: mature/partly spawned, partly spawned, and postspawned/spent as in previous studies of sea urchin gonad histology (Byrne et al. 1998). The mature/partly spawned specimens had in the gonad lumen numerous advanced gametes in good condition, whereas the partly spawned gonads had large spaces in the lumen indicative of major gamete release and the post-spawned/spent gonads had degenerating gametes, no gametes, and/or brown lipofuscin pigment deposits.

The $\mathrm{pH}$ in the coelomic fluid was measured within 2 min using a $\mathrm{pH}$ temperature-corrected $\mathrm{pH}$ meter (OAKTON, USA; pH probe: EUTECH, USA). Subsequently, coelomic fluid was filtered $(0.45-\mu \mathrm{M}$ Minisart filter) and stored cold $\left(4^{\circ} \mathrm{C}\right)$ in acid-washed polypropylene vials until measurements (12 d after sampling) of ion concentrations. The volume of the coelomic fluid of a total of 17 individuals was too small for $\mathrm{pH}$ and ion concentration measurements, leading to an unbalanced sampling design. Ca, $\mathrm{Mg}$, $\mathrm{Na}$, and $\mathrm{K}$ were measured using inductively coupled 
plasma-atomic emission spectrometry (ICP-AES). For comparison, duplicate water samples were taken from each aquarium and measured following the same procedures as for the urchins. All samples were diluted 1/10 using $0.1 \%$ $\mathrm{HNO}_{3}$ as diluent. IAPSO sea water and NASS-5 were analysed repeatedly throughout the sample runs to ensure reproducibility. Variability over the $3 \mathrm{~d}$ of measurements was $<2 \%$ for all ions measured.

\section{Statistical analyses}

Growth rates, respiration, and ammonium excretion rates (both specimen specific and biomass specific) were dependent on the size of the individuals (regression analysis, $p<0.001)$. Thus, these data were analysed using analyses of covariance (ANCOVA). The shape of the relationship resembled a power function, and in most cases, using log-transformed-dependent variables provided the best fit (highest $\mathrm{R}^{2}$ ). Only for biomass-specific excretion rates, the fit was slightly better with the untransformed covariable, and thus, this variable was not transformed in that model. Temperature and $\mathrm{pH}$ were regarded as fixed factors, with average $(N=33)$ readings of temperature and $\mathrm{pH}$ from each individual aquarium. Initial tests including a covariate for gonad indices (based on dry weight of the gonads and remainder) showed that this parameter was independent of the urchin weight for the weight range of the experimental animals. Thus, gonad index was analysed with two-factor analyses of variance (ANOVAs). To account for the appropriate error structure, we tested whether 'aquarium' included in the model as a random nested effect was significant. We retained this factor in all cases where initial test showed $p$ values for 'aquarium' of $<0.25$. Nested ANCOVAS and ANOVAS were run as linear mixed-effect models in R. Histological data of gonad condition were scored into three stages and thus consist of ordinal data. These data were analysed with cumulative link models using the 'ordinal' library in R.

Interaction terms with $p>0.25$ were removed from the models to increase power of the main effects. Assumptions of normality and homogeneity of variances were checked using box plots and residual plots. No deviations from these assumptions were detected in transformed (see results) data. In ANCOVAs, the assumption for homogeneity of slopes was tested by including an interaction between the covariate and the two factors into initial model runs. If this interaction was not significant (the slopes of individual groups were not significantly different), the interaction term was removed. Type III sums of squares were chosen for ANOVAs with unbalanced designs. All statistical analyses were performed in $\mathrm{R}$ ( $\mathrm{R}$ Development Core Team 2012).

\section{Results}

We measured DIC and TA on several occasions at the source population and near a shallower reef flat population in the southern GBR (Electronic Supplementary Material, ESM, Table 1). Depending on tide level and time of the day, $p \mathrm{CO}_{2}$ at the source population varied between 316 and $515 \mu$ Atm. However, due to the remote location and inaccessibility of the site at night-time, measurements during low tides (expected to yield the highest $p \mathrm{CO}_{2}$ ) could not be obtained. Data from One Tree Island illustrate that $p \mathrm{CO}_{2}$ may exceed 1,000 $\mu$ Atm during those situations and can be as low as $240 \mu$ Atm during periods of high productivity during the day (ESM Table 1). The sea surface temperature at the time of collection in September was 24-25 ${ }^{\circ} \mathrm{C}$ and was $23-24{ }^{\circ} \mathrm{C}$ for the previous month. In situ temperature increased in comparison with our control temperature during the course of the experiment. Longterm water temperatures for this region are available (at: http://data.aims.gov.au/aimsrtds/latestreadings.xhtml, see also Collier et al. 2012; Lamare et al. 2014) from a 4-m deep station at Davies Reef ( $\left.18^{\circ} 49.8^{\prime} \mathrm{S}, 147^{\circ} 37.8^{\circ} \mathrm{E}\right)$, a similar midshelf reef to Rib Reef.

Temperatures and $\mathrm{pH}$ values in each individual treatment tank were very close to target values (averages for aquaria and Tanks given in ESM Table 2). $p \mathrm{CO}_{2}$ values of the 'near-future' treatment were in the range expected under RCP 6 to RCP 8.5.

\section{Growth and metabolism}

Most of the Echinometra sp. A (66/72) exhibited measurable growth during the 70-d measuring period, and the weight of the remainder did not change throughout the experiment. Temperature and $\mathrm{pH}$ alone had no significant effects on growth rates (ANCOVA; Table 1; Fig. 1a). However, the interaction between temperature and $\mathrm{pH}$ was marginally significant (Table 1), and a plot of each individual treatment group illustrated that the largest reduction in growth occurred under elevated $p \mathrm{CO}_{2}$ and elevated temperatures $(49.5 \%$ reduction compared to $28{ }^{\circ} \mathrm{C} / \mathrm{pH} 8.1$; Fig. 1b).

Respiration was measured in 60 specimens on day 69 . No effects of the main factors were detected in standard metabolic rate $(\mathrm{SMR}=$ respiration per unit body mass; Table 2), but the interaction between temperature and $p \mathrm{CO}_{2}$ was marginally significant. This was caused by the highest respiration rates being measured in the high temperature/high $p \mathrm{CO}_{2}$ treatment (Fig. 2). However, the value in the latter treatment was only $5.9 \%$ above that for the present day 'control' treatment.

Respiration per specimen was significantly higher in the high temperature treatment (Table 2; Fig. 2b). However, for this parameter, the interaction term was also marginally 
Table 1 Analysis of covariance for the growth of Echinometra sp. $A$ in two temperature and two $p \mathrm{CO}_{2}$ treatments

\begin{tabular}{lccrrr}
\hline & $\mathrm{DF}_{\text {Nom }}$ & $\mathrm{DF}_{\text {Denom }}$ & \multicolumn{1}{l}{$\mathrm{MS}$} & \multicolumn{1}{l}{$F$} & \multicolumn{1}{l}{$p$} \\
\hline Temperature & 1 & 8 & 4.198 & 2.87 & 0.1289 \\
$\mathrm{pH}$ & 1 & 8 & 0.247 & 0.17 & 0.6919 \\
Temp $\times \mathrm{pH}$ & 1 & 8 & 5.077 & 3.49 & 0.0987 \\
Initial weight & 1 & 59 & 36.175 & 27.96 & $<0.0001$ \\
Residuals & 67 & & 1.168 & & \\
\hline
\end{tabular}

Response parameter is the percentage growth of specimens after $70 \mathrm{~d}$ (log-transformed, 0.1 added to accommodate zero values), and covariate is the initial weight (log-transformed) of the echinoids. Initial analysis confirmed that slopes were not significantly different (Temperature $\times \mathrm{pH} \times$ initial weight interaction: $F_{1,56}=0.27$, $p=0.6019$ ). The random factor 'aquarium' added $18.18 \%$ to the variance. $\mathrm{DF}_{\mathrm{Nom}}$; $\mathrm{DF}_{\text {Denom }}$ : Degrees of freedom for the nominator and denominator for the $F$-tests, respectively

significant. The combined stressor (high temperature/high $p \mathrm{CO}_{2}$ ) treatment was $22.1 \%$ above the value for the control.

Ammonia excretion rates from 12 specimens per treatment were measured on day 75 of the experiment. Weight-specific ammonium excretion was elevated in the $31{ }^{\circ} \mathrm{C}$ treatment (average $44.80 \mathrm{nmol} \mathrm{NH}_{4} \mathrm{~h}^{-1}, \mathrm{SE}=2.27 \mathrm{nmol} \mathrm{NH}_{4} \mathrm{~h}^{-1}$; Table 3) compared to the $28{ }^{\circ} \mathrm{C}$ (average $39.43 \mathrm{nmol} \mathrm{NH}_{4}$ $\mathrm{h}^{-1} \mathrm{~g}^{-1}, \mathrm{SE}=2.06 \mathrm{nmol} \mathrm{NH}_{4} \mathrm{~h}^{-1}$ ), but this effect was only marginally significant. Per specimen values were significantly higher in the elevated temperature treatment $\left(31^{\circ} \mathrm{C}\right.$ average $1.70 \mu \mathrm{mol} \mathrm{NH} \mathrm{NH}_{4} \mathrm{~h}^{-1}, \quad \mathrm{SE}=0.08 \mu \mathrm{mol} \mathrm{NH} \mathrm{NH}_{4} \mathrm{~h}^{-1} ; \quad 28{ }^{\circ} \mathrm{C}$ average $1.40 \mu \mathrm{mol} \mathrm{NH} \mathrm{N}_{4} \mathrm{~h}^{-1}, \mathrm{SE}=0.08 \mu \mathrm{mol} \mathrm{NH} \mathrm{N}^{-1}$; Table 3). Similar to respiration rates, both excretion parameters showed highest rates at the high temperature/high $p \mathrm{CO}_{2}$ treatment (Fig. 3). However, the interaction term of the ANCOVA was not significant for weight-specific rates and specimen-specific rates (Table 3 ).

There was no significant difference between O:N ratios caused by the temperature or $\mathrm{pH}$ treatment (Table 3), with an overall mean value of $44.4(1 \mathrm{SE}=1.56, N=48)$.

Gonad index and histological condition

Gonad indices were not significantly different between $\mathrm{pH}$ treatments, and temperature by $\mathrm{pH}$ interactions was not
Fig. 1 Growth of Echinometra sp. $A$ (as percentage of initial weight) affected by a temperature and $\mathbf{b}$ the interaction between temperature and elevated $p \mathrm{CO}_{2}$. Boxes for $28^{\circ} \mathrm{C}$ are filled grey, $31^{\circ}$ white. Whiskers denote $1.5 \times$ the inter-quartile range, the black line indicates the mean

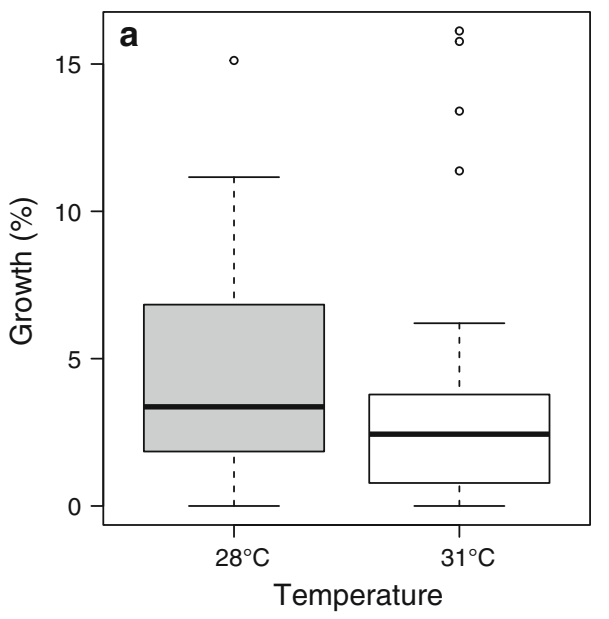

Table 2 Analysis of covariance for respiration of Echinometra sp. $A$ in two temperature and two $p \mathrm{CO}_{2}$ treatments

\begin{tabular}{|c|c|c|c|c|c|c|c|c|}
\hline & \multirow[t]{2}{*}{$\mathrm{DF}_{\mathrm{Nom}}$} & \multirow[t]{2}{*}{$\mathrm{DF}_{\text {Denom }}$} & \multicolumn{3}{|l|}{ SMR } & \multicolumn{3}{|c|}{ Per specimen } \\
\hline & & & MS & $F$ & $p$ & MS & $F$ & $p$ \\
\hline Temperature & 1 & 8 & 0.0058 & 1.7 & 0.229 & 0.2833 & 13.20 & 0.0067 \\
\hline $\mathrm{pH}$ & 1 & 8 & 0.0002 & 0.13 & 0.7286 & 0.0475 & 2.37 & 0.1623 \\
\hline Temp $\times p H$ & 1 & 8 & 0.0136 & 4.06 & 0.0788 & 0.0904 & 4.10 & 0.0774 \\
\hline Weight & 1 & 46 & 0.0231 & 50.65 & $<0.0001$ & 1.1454 & 62.31 & $<0.0001$ \\
\hline Residuals & 54 & & 0.0214 & & & 0.0177 & & \\
\hline
\end{tabular}

Response parameters are standard metabolic rate (SMR, respiration per g wet weight of $E$. sp. $A$ ) or per specimen respiration rate. Both parameters were log-transformed, and covariate is the weight of the echinoids. (Temperature $\times \mathrm{pH} \times$ initial weight interaction: SMR: $F_{1,43}=0.08, p=0.7831$, per specimen: $\left.F_{1,43}=0.04, p=0.8364\right)$. The random factor 'aquarium' added $18.91 \%$ to the variance for SMR and $18.68 \%$ for per specimen value. $\mathrm{DF}_{\mathrm{Nom}}$; $\mathrm{DF}_{\text {Denom }}$ : Degrees of freedom for the nominator and denominator for the $F$-tests, respectively

Bold value indicates $p<0.05$ 

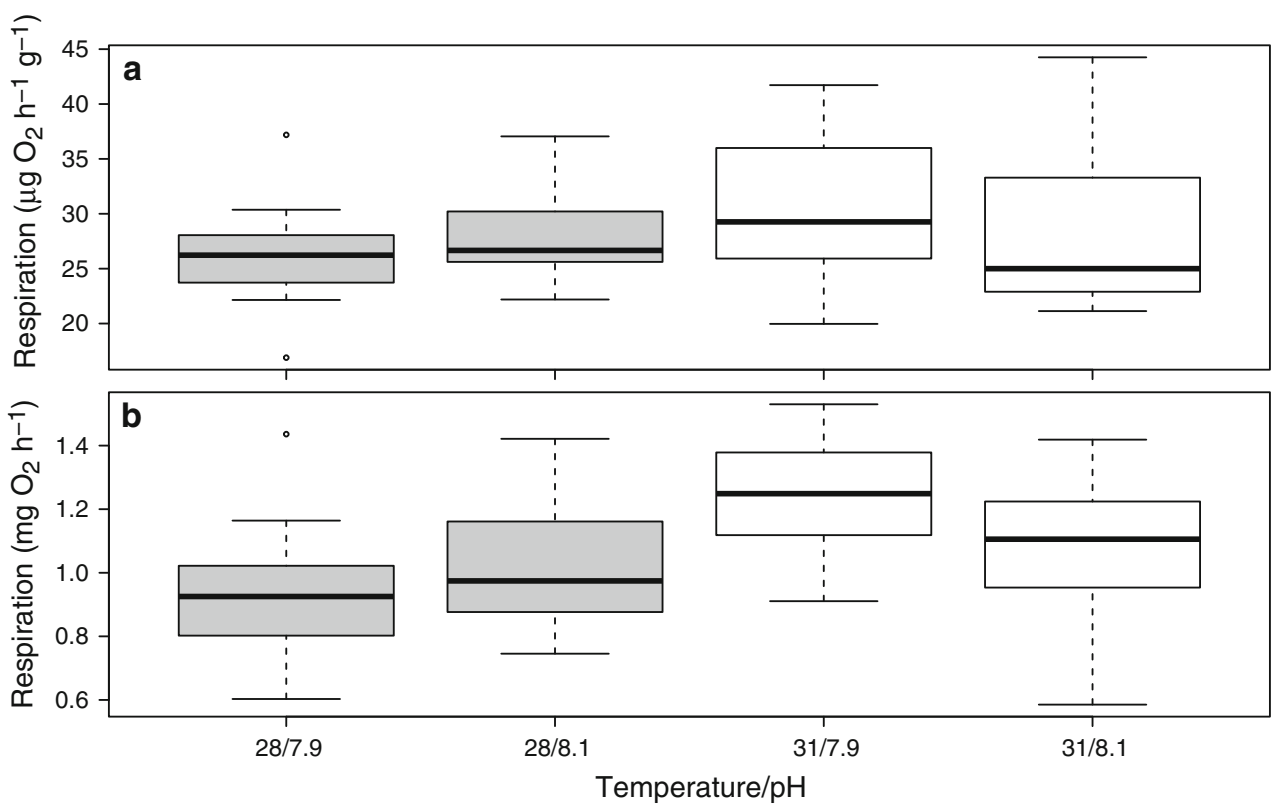

Fig. 2 Respiration of Echinometra sp. A as standard metabolic rate a standardised per gram of wet weight of the specimens or $\mathbf{b}$ per modelled out for statistical analysis (see Table 2). Boxes for $28{ }^{\circ} \mathrm{C}$ specimen, and differences caused by different-sized urchins were treatments are filled grey, $31{ }^{\circ} \mathrm{C}$ white. Whiskers denote $1.5 \times$ the inter-quartile range, and the black line indicates the mean

Table 3 Analysis of covariance for excretion of Echinometra sp. A in two temperature and two $p \mathrm{CO}_{2}$ treatments

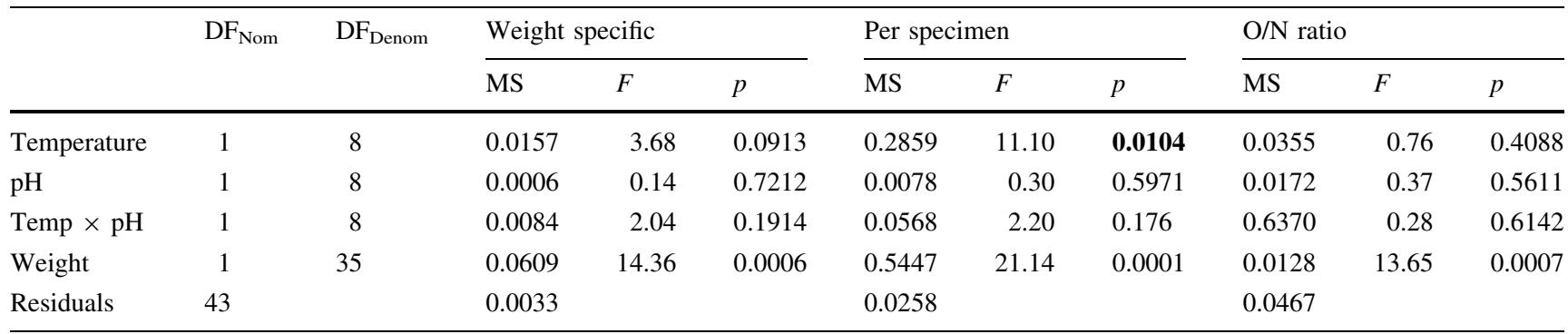

Response parameters are weight-specific rate (excretion per g wet weight) or per specimen excretion rate. Both parameters were log-transformed, and covariate is the weight of the echinoids (homogeneity of slopes test for ANCOVA: Temperature $\times \mathrm{pH} \times$ initial weight interaction: weight specific: $F_{1,32}=0.05, p=0.8266$; per specimen: $F_{1,32}=0.03, p=0.8711$, O:N ratio: $\left.F_{1,32}=0.07, p=0.7999\right)$. The random factor 'aquarium' added $<0.01 \%$ to the variance for weight-specific excretion, $3.35 \%$ for per specimen value and $<0.01 \%$ for $\mathrm{O}: \mathrm{N}$ ration. $\mathrm{DF}_{\mathrm{Nom}}$; $\mathrm{DF}_{\text {Denom: }}$ : Degrees of freedom for the nominator and denominator for the $F$-tests, respectively

Bold value indicates $p<0.05$

significant for all individuals pooled, males or females (Table 4). In contrast, gonad indices were higher in the lower temperature treatment, and this was significant for all individuals pooled and for males (Fig. 4; Table 4).

Gonad histological condition differed amongst treatments (Figs. 5, 6). For the females, there was a marginally significant effect of temperature and the interaction of temperature and $\mathrm{pH}$ on the distribution of histological stages (Table 5). Ovaries from urchins maintained in control conditions had abundant mature eggs (Fig. 5) and were in the mature or partly spawned condition. With increased temperature and decreased $\mathrm{pH}$, ovary condition declined with an increase in the number of individuals in the post-spawned or spent condition (Fig. 6). These ovaries had few or no eggs in the lumen, and many had degenerating eggs and accumulations of lipofuscin pigment granules (Fig. 5). No females in the control treatment were in the post-spawned category.

Differences in histological categories were more distinct in the males, with the effect of $\mathrm{pH} / \mathrm{high} p \mathrm{CO}_{2}$ and the interaction being significant (Table 5). With the exception of the high temperature and low $\mathrm{pH} / \mathrm{high} p \mathrm{CO}_{2}$ treatment, $\sim 50 \%$ of the testes were mature. Testis condition clearly declined in the low pH treatments (Figs. 5, 6), and most distinctly so in the high temperature low $\mathrm{pH}$ treatment, where no mature gonads were detected. The latter finding agrees with the significant interaction between the two stressors seen with statistical analysis, suggesting a synergistic effect. 


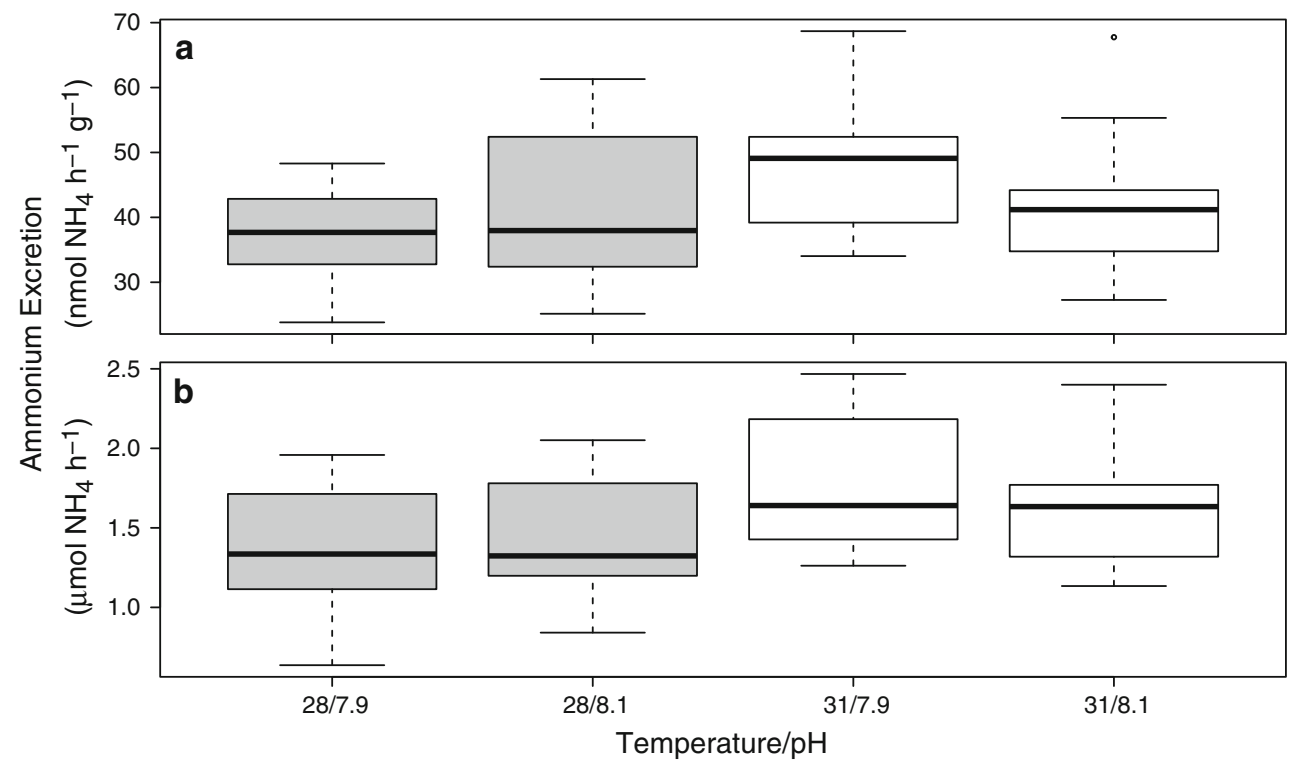

Fig. 3 Ammonium excretion rates of Echinometra sp. A as a weightspecific rate (standardised per gram of wet weight of the specimens) or $\mathbf{b}$ per specimen, and differences caused by different sized urchins

Table 4 Analysis of variance for gonad indices of Echinometra sp. $A$ in two temperature and two $p \mathrm{CO}_{2}$ treatments

\begin{tabular}{lrlrl}
\hline & Df & MS & $F$ & $p$ \\
\hline $\begin{array}{l}\text { All individuals } \\
\text { Temperature }\end{array}$ & 1 & 0.00560 & 4.38 & $\mathbf{0 . 0 4 0 0}$ \\
$\mathrm{pH} / p \mathrm{CO}_{2}$ & 1 & 0.00003 & 0.02 & 0.8825 \\
Residuals & 68 & 0.00128 & & \\
Males & & & & \\
Temperature & 1 & 0.003563 & 5.08 & $\mathbf{0 . 0 3 0 6}$ \\
$\mathrm{pH} / p \mathrm{CO}_{2}$ & 1 & 0.000001 & $<0.01$ & 0.9734 \\
Residuals & 37 & 0.000705 & & \\
Females & & & & \\
Temperature & 1 & 0.003716 & 1.86 & 0.1838 \\
$\mathrm{pH} / p \mathrm{CO}_{2}$ & 1 & 0.000002 & 0.00 & 0.9776 \\
Residuals & 27 & 0.001997 & & \\
\end{tabular}

Response parameter is the gonad index based on dry weights. Gonad index was arcsine-square-root-transformed. Interactions between temperature and $\mathrm{pH}$ and the random factor 'aquarium' were removed from models because they were highly $(>0.25)$ non-significant. Type III sums of squares were chosen because the design for these analyses is unbalanced

Bold values indicates $p<0.05$

\section{Coelomic fluid}

The $\mathrm{pH}$ of the coelomic fluid was lower than in the external treatment water of the aquaria. Although the coelomic fluid from Echinometra sp. A from the control pH 8.1 treatment was higher (mean $\mathrm{pH}=7.56, \mathrm{SD}=0.05$ ) than that from the urchins kept at $\mathrm{pH} 7.9$ (mean $\mathrm{pH}=7.52, \mathrm{SD}=0.07$ ), were modelled out for statistical analysis (see Table 3). Boxes for $28{ }^{\circ} \mathrm{C}$ treatments are filled grey, $31{ }^{\circ} \mathrm{C}$ white. Whiskers denote $1.5 \times$ the inter-quartile range, and the black line indicates the mean
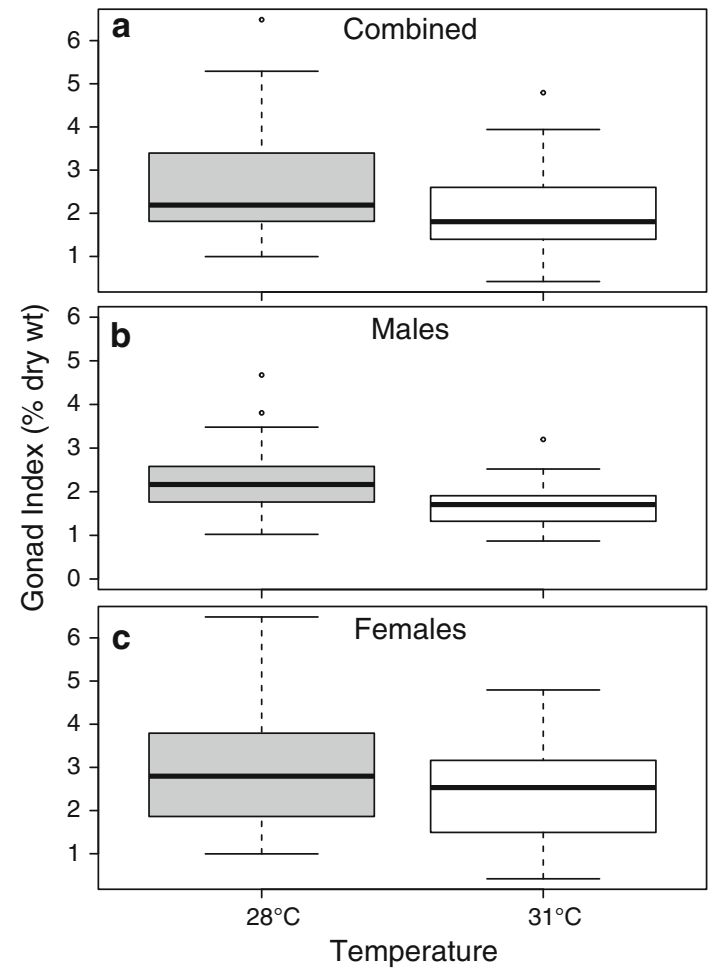

Fig. 4 Gonad index (based on dry body weight and dry gonad weight of Echinometra sp. A (a all individuals, $\mathbf{b}$ males, $\mathbf{c}$ females). Boxes for $28{ }^{\circ} \mathrm{C}$ treatments are filled grey, and $31{ }^{\circ} \mathrm{C}$ treatments in white. Whiskers denote $1.5 \times$ the inter-quartile range, and the black line indicates the mean

this effect was not statistically significant (Table 6). Temperature had also no measurable effect on coelomic fluid $\mathrm{pH}$ (Table 6). 

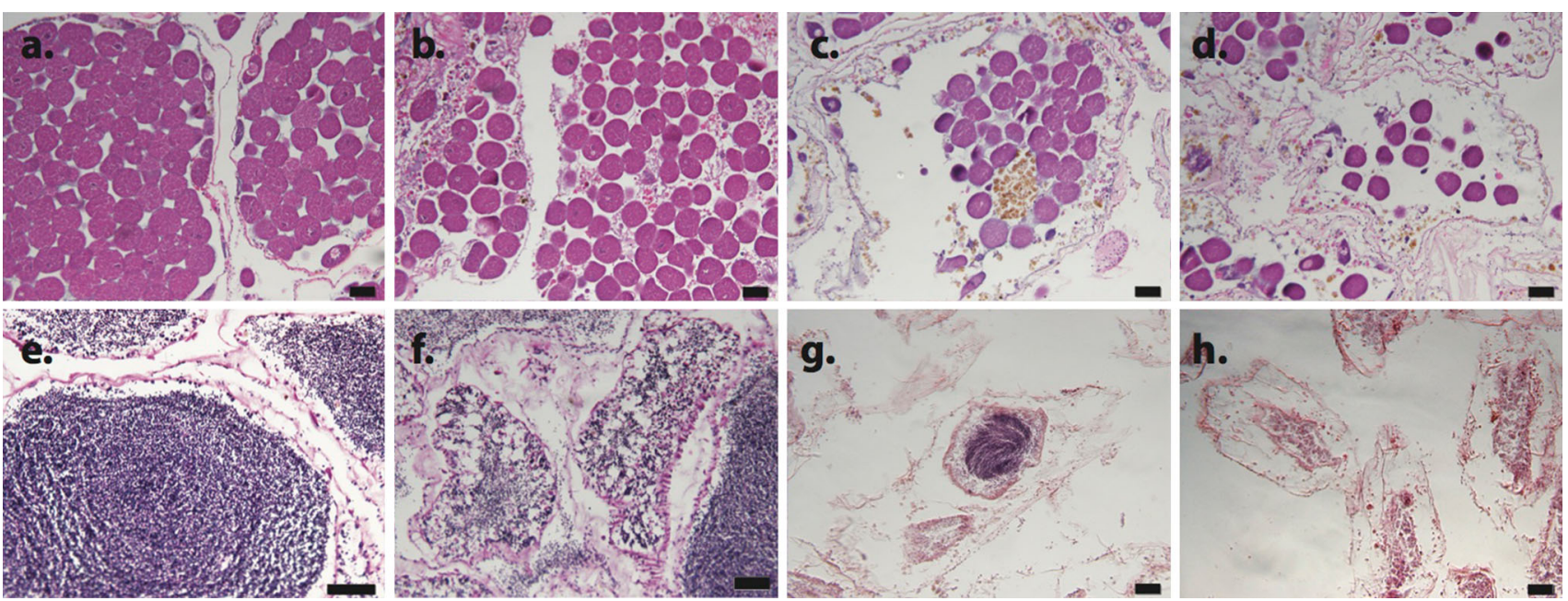

Fig. 5 Histology of the gonads of female (a-d) and male (eh) Echinometra sp. $A$ held in experimental treatments for $77 \mathrm{~d}$. The gonads of urchins maintained in control conditions had an abundance of mature gametes $(\mathbf{a}, \mathbf{e})$ or were partly spawned $(\mathbf{b}, \mathbf{f})$. In the other

treatments, the gonads were post-spawned/spent $(\mathbf{c}, \mathbf{d}, \mathbf{g}, \mathbf{h})$ with empty gonad tubules and lipofuscin-like pigment accumulations (e.g., in centre of c). Scale bars $=100 \mu \mathrm{m}$

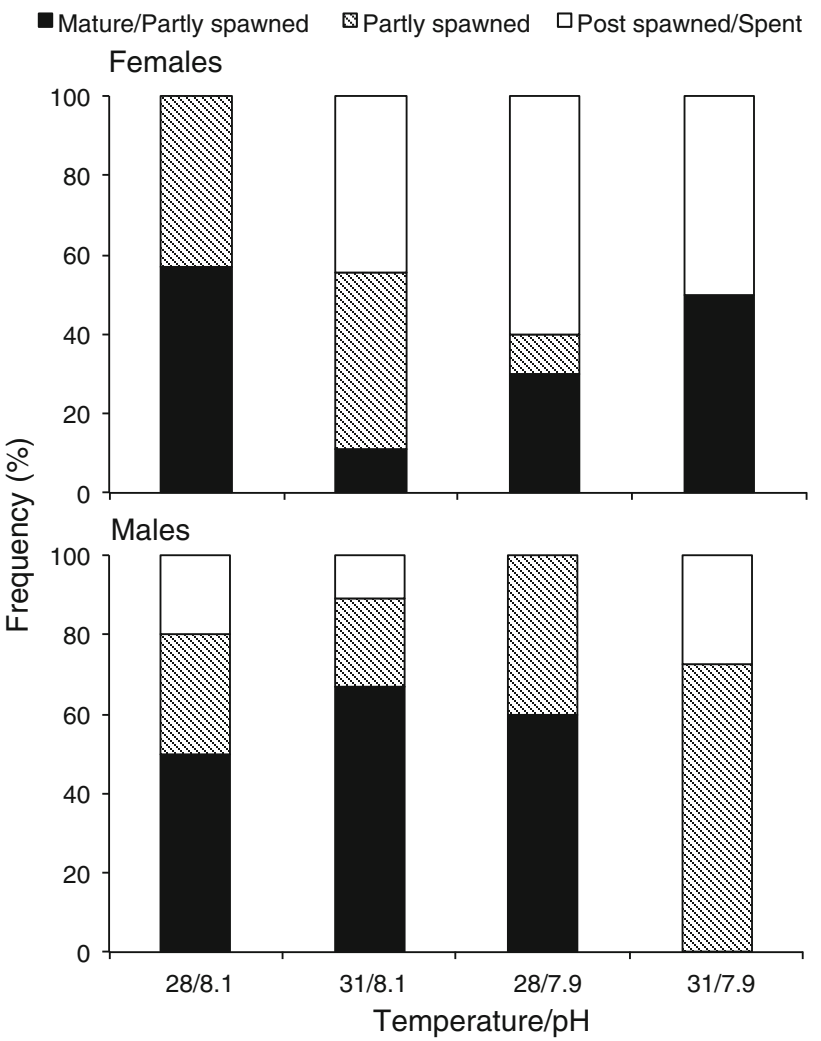

Table 5 Cumulative link model analysis for ordinal data for female (total $N=34)$ and male $(N=35)$ Echinometra sp. $A$

\begin{tabular}{lrrrl}
\hline & Slope & SE & $z$ & $p$ \\
\hline Females & & & & \\
Temperature & -1.75 & 0.93 & -1.88 & 0.0603 \\
$\mathrm{pH} / \mathrm{pCO}_{2}$ & -0.63 & 0.94 & -0.67 & 0.501 \\
Temp $\times \mathrm{pH}$ & 2.51 & 1.36 & 1.84 & 0.0661 \\
Males & & & & \\
Temperature & 0.84 & 0.97 & 0.88 & 0.3815 \\
$\mathrm{pH} / \mathrm{pCO}{ }_{2}$ & 2.54 & 0.99 & 2.56 & $\mathbf{0 . 0 1 0 4}$ \\
Temp $\times \mathrm{pH}$ & -3.29 & 1.50 & -2.19 & $\mathbf{0 . 0 2 8 3}$ \\
\hline
\end{tabular}

Response data are three stages (mature/partly spawned, partly spawned, post-spawned/spent) of the gonad condition based on histology

Bold values indicates $p<0.05$

detected for any of the four ions measured (2-factor ANOVA, $p>0.1$ for each factor and the interaction term). Compared to the external medium, calcium, magnesium and sodium were significantly decreased (indicated by nonoverlapping standard deviations, Fig. 7). Potassium was in the same range in the coelomic fluid and in the aquarium water.

Internal concentrations of calcium, magnesium and sodium exhibited no differences between temperature or pH treatments (Table 6; Fig. 7). ANOVA for potassium had a marginally significant interaction term between temperature and $\mathrm{pH}$, with values at the 28/7.9 and 31/8.1 treatments elevated above the other treatments (Fig. 7). However, values within these groups are also more variable, and averages only vary by a small amount (7-8\%) between treatments. 
Table 6 Analysis of variance $\mathrm{pH}$ and ion concentrations in the coelomic fluid of Echinometra sp. $A$ in two temperature and two $p \mathrm{CO}_{2}$ treatments

\begin{tabular}{|c|c|c|c|c|c|}
\hline & $\mathrm{DF}_{\mathrm{Nom}}$ & $\mathrm{DF}_{\text {Denom }}$ & MS & $\mathrm{F}$ & $p$ \\
\hline \multicolumn{6}{|l|}{ Coelomic pH } \\
\hline Temperature & 1 & 35 & $<0.00001$ & 0.04 & 0.8482 \\
\hline $\mathrm{pH}$ & 1 & 35 & 0.00021 & 2.75 & 0.106 \\
\hline Residual & 35 & & 0.00008 & & \\
\hline \multicolumn{6}{|l|}{$\mathrm{Ca}$} \\
\hline Temperature & 1 & 9 & 0.12900 & $<0.01$ & 0.9563 \\
\hline $\mathrm{pH}$ & 1 & 9 & 3.15200 & $<0.01$ & 0.9687 \\
\hline Residual & 52 & & 329.06629 & & \\
\hline \multicolumn{6}{|l|}{$K$} \\
\hline Temperature & 1 & 8 & 0.00428 & 0.41 & 0.5379 \\
\hline $\mathrm{pH}$ & 1 & 8 & 0.00254 & 0.16 & 0.6954 \\
\hline Temperature $\times \mathrm{pH}$ & 1 & 8 & 0.04549 & 3.61 & 0.0938 \\
\hline Residual & 51 & & 0.00861 & & \\
\hline \multicolumn{6}{|l|}{$M g$} \\
\hline Temperature & 1 & 9 & 0.00006 & 0.02 & 0.8995 \\
\hline $\mathrm{pH}$ & 1 & 9 & 0.00049 & 0.19 & 0.6727 \\
\hline Residual & 52 & & 0.00245 & & \\
\hline \multicolumn{6}{|l|}{$\mathrm{Na}$} \\
\hline Temperature & 1 & 9 & 0.00001 & 0.00 & 0.9607 \\
\hline $\mathrm{pH}$ & 1 & 9 & 0.00166 & 0.16 & 0.6976 \\
\hline Residual & 52 & & 0.00750 & & \\
\hline
\end{tabular}

All parameters were log-transformed for analysis. With the exception of $\mathrm{K}$, interactions between temperature and $\mathrm{pH}$ were removed from models because they were highly $(>0.25)$ non-significant; the random factor 'aquarium' was removed from the model for $\mathrm{pH}$ of the coelomic fluid. Aquarium added 15.88, 23.32, 6.34, and $18.04 \%$ to the variance of the models for $\mathrm{Ca}, \mathrm{K}, \mathrm{Mg}$, and $\mathrm{Na}$, respectively. Type III sums of squares were chosen because the design for these analyses was unbalanced. $\mathrm{DF}_{\mathrm{Nom}}$; $\mathrm{DF}_{\text {Denom }}$ : Degrees of freedom for the nominator and denominator for the $F$-tests, respectively

\section{Discussion}

Our experiments showed that some of the basic metabolic parameters (growth, respiration, ammonium excretion) of the ecologically important sea urchin Echinometra sp. $A$ responded to temperature and/or $\mathrm{pH}$ changes. Growth at the high temperature/high $p \mathrm{CO}_{2}$ treatment was reduced, whereas respiration and ammonium excretion increased in that treatment compared to the 'present-day' control. Our initial hypothesis that the interaction of increased temperature and $p \mathrm{CO}_{2}$ at levels expected by the end of this century under most representative concentration pathways (Meinshausen et al. 2011) leads to higher stress than the individual stress alone can thus be accepted. However, our study also illustrated that the effects on adults are not large, at least over the 10-week time scale of our study, and in several cases only marginally significant. Echinometra sp $A$. and other shallow-water reef species are acclimatised to the large (nearly from 250 to $1,300 \mu \mathrm{mol}$ ) daily changes in $p \mathrm{CO}_{2}$ that they experience over the tidal cycle. However, during less extreme tides and in deeper water, fluctuations in $p \mathrm{CO}_{2}$ were much smaller.

\section{Metabolism}

We previously showed that the growth of Echinometra sp. $A$ (addressed as $E$. mathaei) subtly decreased in response to decreased $\mathrm{pH} /$ increased $p \mathrm{CO}_{2}$ (Uthicke et al. 2013), which was in agreement with other data on Echinometra species in Japan (Shirayama and Thornton 2005). Although the response to increased $p \mathrm{CO}_{2} /$ decreased $\mathrm{pH}$ is not always linear, all four other echinoid species thus far investigated can be expected to exhibit reduced growth in near-future OA conditions (Ries et al. 2009; Albright et al. 2012; Stumpp et al. 2012b). In the present experiment, the relatively mild change in $p \mathrm{CO}_{2} / \mathrm{pH}$ alone did not result in significantly reduced growth. A $p \mathrm{CO}_{2}$ change of similar magnitude applied in Shirayama and Thornton (2005) only resulted in differences in size after longer ( $>12$ weeks) experimental periods. In our study, the largest reduction was seen when temperature was elevated and $\mathrm{pH}$ decreased $/ p \mathrm{CO}_{2}$ increased.

As for most poikilothermic invertebrates, echinoid metabolism follows the $\mathrm{Q}_{10}$ rule and increases with temperature increase (Ulbricht and Pritchard 1972). This was 
Fig. 7 Ion concentration in the coelomic fluid of Echinometra sp. A. Treatment levels (Temperature/pH) are listed on the horizontal axes. Boxes for $28{ }^{\circ} \mathrm{C}$ treatments are filled grey and, $31{ }^{\circ} \mathrm{C}$ white. Horizontal lines represent the mean (solid line) and standard deviation (dashed line) of the average aquarium water, and exact values for these were $413 \mathrm{mg} \mathrm{L}^{-1}$ (1

$\left.\mathrm{SD}=5 \mathrm{mg} \mathrm{L}^{-1}\right)$ for $\mathrm{Ca}$, $389 \mathrm{mg} \mathrm{L}^{-1}(1$

$\mathrm{SD}=5 \mathrm{mg} \mathrm{L}^{-1}$ ) for $\mathrm{K}$, $1,323 \mathrm{mg} \mathrm{L}^{-1}$ $\left(1 \mathrm{SD}=11 \mathrm{mg} \mathrm{L}^{-1}\right)$ for $\mathrm{Mg}$, $1.07 \mathrm{mg} \mathrm{L}^{-1}$ (1 $\left.\mathrm{SD}=0.01 \mathrm{mg} \mathrm{L}^{-1}\right)$ for $\mathrm{Na}$
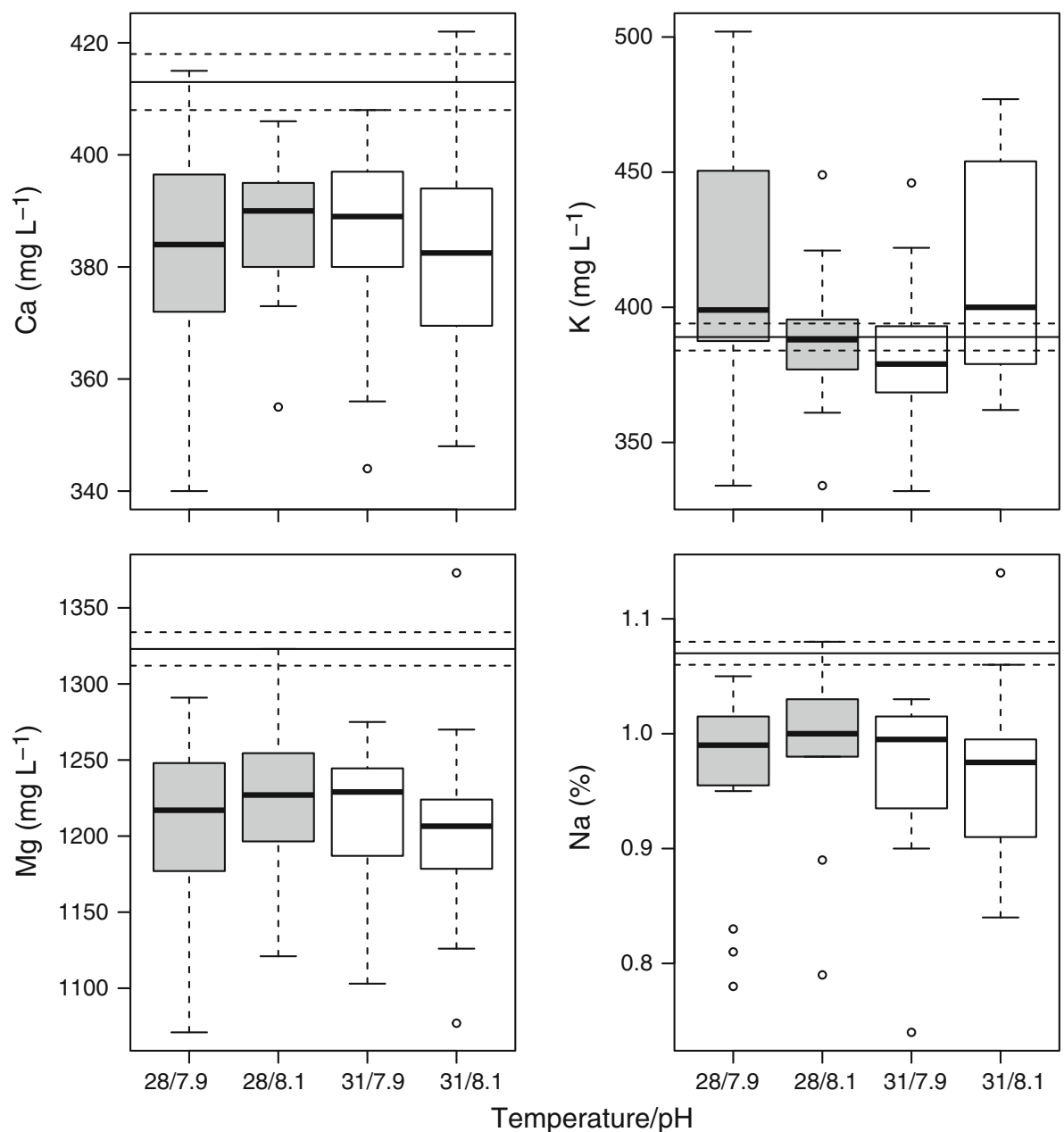

also observed here for respiration and ammonium excretion, although the increase in respiration was subtle and not significant. For both parameters, the highest metabolic rate was observed in the high temperature/high $p \mathrm{CO}_{2}$ treatment.

Responses of echinoderm respiration to $\mathrm{pH}$ changes vary widely and often deviate from the assumption that low $\mathrm{pH} /$ hypercapnia induces metabolic depression in marine invertebrates (Pörtner et al. 2004; Pörtner 2008). In a previous study, we showed that respiration in Echinometra sp. $A$ can be subtly reduced under intermediate $p \mathrm{CO}_{2}$ conditions (785-1,261), but were at the same level as the control at 1,786 $\mu$ ATM $\mathrm{CO}_{2}$ (Uthicke et al. 2013). A similar pattern was also observed for temperate ophiuroids and asteroids (Christensen et al. 2011; McElroy et al. 2012). Two boreal-temperate ophiuroid species exhibited increased metabolic rates with decreasing $\mathrm{pH}$ (Wood et al. 2008, 2011). In the present study, $\mathrm{pH}$ had a slightly enhancing effect on respiration, but this was more distinct under elevated temperatures.

Ammonium excretion rates in tropical holothurians in summer were also higher than those at colder temperatures (Uthicke 2001). A previous study on a temperate echinoid species detected clearly higher ammonium excretion rates under elevated $p \mathrm{CO}_{2}$, but only under treatment conditions much higher than used here ( 2,800 uATM; Stumpp et al. $2012 b$ ). The latter study also observed reduced O:N ratios, which was interpreted as higher protein catabolism as an additional mechanism for removing protons. Reduced O:N ratios are generally interpreted as a shift in substrate for oxidative metabolism, e.g., towards monoamino dicarboxylic amino acids (Langenbuch and Pörtner 2002). O:N ratios in our study were high, as expected for herbivorous echinoids (Otero-Villanueva et al. 2004), but showed no difference between treatments.

Several studies have investigated the interactive effects of temperature and $\mathrm{pH}$ on echinoderm metabolism. Low $\mathrm{pH}$ only leads to metabolic upregulation in Ophiura ophiura when in combination with a low temperature treatment (Wood et al. 2010). However, due to lower saturation of calcite, the high temperature/low $\mathrm{pH}$ treatment of that study required relocation of energy to maintain calcification. The temperate echinoid Paracentrotus lividus also only increased metabolism with reduced $\mathrm{pH}$ under simultaneous reduction of temperature (Catarino et al. 2012). In 
contrast to the latter study, several parameters measured in Ophiocten sericeum showed no interactive effects between $\mathrm{pH}$ and temperature; only arm regeneration was reduced when subjected to extreme low $\mathrm{pH}$ in combination with temperature stress (Wood et al. 2011). Also Ophionereis shayeri exhibited interactive effects on temperature and $\mathrm{pH}$ on respiration (Christensen et al. 2011). In that study, specimens kept at the lowest $\mathrm{pH}$ (7.6) showed a smaller reduction in respiration when held in lower temperature than control and intermediate $\mathrm{pH}$ specimens $(\mathrm{pH} 8.2$ and 7.8). As for most studies mentioned above, temperature had a stronger effect on respiration of the asteroid Parvulastra exigua than reduced $\mathrm{pH} /$ increased $p \mathrm{CO}_{2}$ (McElroy et al. 2012). However, under the lowest $\mathrm{pH}$ treatment, temperature increase above $21{ }^{\circ} \mathrm{C}$ does not further increase respiration, in the latter study.

\section{Gonads}

Increased temperature $\left(+3{ }^{\circ} \mathrm{C}\right)$ resulted in a decrease in the gonad index, which was most pronounced (and significant) for the males. No effect of $\mathrm{pH}$ could be detected although in a previous study, we observed that males held under similar $\mathrm{pH}$ conditions as used here had a reduced ability to spawn (Uthicke et al. 2013). An impact on female fecundity after 4 months of exposure to elevated $\mathrm{pCO}_{2}$ was also observed in Strongylocentrotus droebachiensis, but this effect was not present in animals acclimated for longer periods (Dupont et al. 2012). After an exposure of 9 months, individuals of Hemicentrotus pulcherrimus exposed to elevated $\mathrm{pCO}_{2}$ delayed spawning and gonad development by 1 month (Kurihara et al. 2013). Histological examination indicated that the gonads of most of the Echinometra sp. A held under conditions other than the control had fewer mature gametes. For the females, gonad condition indicated degeneration/resorption of the eggs or differential gamete release in high temperature and low $\mathrm{pH}$ treatments. For the males, decline in gonad condition was seen in the low $\mathrm{pH}$ treatments, and a synergistic effect of the stressors $\mathrm{pH}$ and temperature was suggested. It seems that both females and males may have released gametes over the incubation period. Spawning, however, was not observed and may have occurred at night. The urchins from the control tanks are likely to have continued to recruit gametes to the lumen (supported by the feeding regime) in continual gamete development as occurs over the long approximately 5- to 6-month spawning period of this urchin on the GBR (M Byrne pers. obs.). In contrast, gonads of urchins in treatments with elevated temperature and/or elevated $p \mathrm{CO}_{2}$ were unable to generate new cohorts of gametes.

The response of the gonads to high temperature/low $\mathrm{pH}$ conditions may have been an acute disturbance response rather than a response on gonad development. However, given the difference observed between the treatments, gonad condition is also an indicator of stress on the metabolism of the urchins. The differences in the response of gonad development in experimental treatments, based on data from weight and histological condition, show that the use of a gonad index can only provide a proxy of organism response, as shown in other studies of sea urchin reproduction (Byrne 1990; Byrne et al. 1998). In order to determine the reproductive response of sea urchins and other organisms to ocean change conditions, it will be important to maintain the brood stock in experimental conditions from the outset of gonad development cycle or conduct studies in organisms under naturally elevated $\mathrm{pCO}_{2}$ such as those on vent systems (Hall-Spencer et al. 2008; Fabricius et al. 2011).

The boreal-temperate echinoid Strongylocentrotus droebachiensis exhibited reduced gonadal growth in treatments with $>1,000 \mu \mathrm{ATM} p \mathrm{CO}_{2}$ compared to controls (Stumpp et al. 2012b). Several studies examined gonad development in echinoids under different temperatures from an aquaculture perspective. For instance, gonads of the $S$. droebachiensis showed little differences in development in two treatments differing by $9{ }^{\circ} \mathrm{C}$ temperature (Garrido and Barber 2001). In contrast, gonadal growth in the temperate species Paracentrotus lividus was reduced when temperature exceeded $22{ }^{\circ} \mathrm{C}$ (ambient $=$ up to $24{ }^{\circ} \mathrm{C}$ in summer; Shpigel et al. 2004). In the latter studies and for the data presented here, it is possible that higher energy demand through faster metabolism at higher temperatures reduced energy availability for gonad development. These responses may also reflect the general trend in ectotherms ascribed to the temperature size rule, with facilitation of growth by moderate warming up to thermal limits where growth decreases (Sheridan and Bickford 2011).

\section{Coelomic fluid}

Amongst echinoderms, echinoids have the highest buffer capacity of the coelomic fluid to ambient $p \mathrm{CO}_{2}$ increase (Collard et al. 2013). The intestine of these animals can act as a barrier for bicarbonate ions and is selective for ion diffusion (Holtmann et al. 2013).

Coelomic fluid $\mathrm{pH}$ in the tropical species investigated here was at similar low levels as reported for temperate echinoids (Miles et al. 2007; Spicer et al. 2011); more extreme values (down to $\sim \mathrm{pH}$ 7.2) were observed during emersion (Burnett et al. 2002).

Coelomic fluid $\mathrm{pH}$ of $S$. droebachiensis decreased significantly (acidosis) after $4 \mathrm{~d}$ of exposure to moderately and highly elevated $(>1,400 \mu \mathrm{ATM}) p \mathrm{CO} 2$, but values recovered after a longer exposure, possibly due to carbonate dissolution of the test (Spicer et al. 2011). Similarly, 
$\mathrm{pH}$ in the coelomic fluid dropped sharply in Psammechinus miliaris after short-term (days) exposure and recovered slightly after longer exposure periods (Miles et al. 2007). Decreased external $\mathrm{pH}$ also reduced coelomic fluid $\mathrm{pH}$ significantly in Paracentrotus lividus after a 19-d exposure (Catarino et al. 2012). All of the above studies were conducted under distinctly higher $p \mathrm{CO}_{2}$ increase than in the present study. This and the fact that our experiment also constitutes a longer term exposure (77 d) may explain why no significant decrease in $\mathrm{pH}$ of the coelomic fluid was observed in Echinometra sp. A.

Miles et al. (2007) described increases in magnesium in the coelomic fluid under increased $p \mathrm{CO}_{2}$ and interpreted this finding as indication for $\mathrm{Mg}$ calcite dissolution. Also calcium concentrations in the coelomic fluid can increase with increased $p \mathrm{CO}_{2}$ (Spicer et al. 2011). Magnesium and calcium in the coelomic fluid of Paracentrotus lividus also did not change with external $\mathrm{pH}$, but were altered by temperature (Catarino et al. 2012). In our study, both magnesium and calcium showed no significant differences between treatments, but values of both elements were significantly lower than in the surrounding sea water. This is an indicator that calcification still occurs under mild ocean acidification as mimicked in our experiments. The fact that urchins in all treatments still achieved positive growth supports this interpretation.

Sodium and potassium in $S$. droebachiensis remained unaffected by increased $p \mathrm{CO}_{2}$ (Spicer et al. 2011), but no comparison was given to the external medium. In the present study, sodium was not affected by treatment, but was also lower than in the aquarium water. It is unclear what caused the apparently erratic pattern in potassium values in the coelomic fluid, with values similar to the external medium in two treatments, and more variation and slightly elevated values in the remaining two (28/7.9 and 31/8.1).

In summary, we detected evidence that interactive effects of likely near-future conditions of elevated SST and elevated $p \mathrm{CO}_{2} /$ reduced $\mathrm{pH}$ will change the metabolism and have significant negative effects on growth of Echinometra sp A. However, effects were subtle, and ultimately most animals were still able to calcify and grow under those conditions. Densities of adult coral reef echinoids including Echinometra spp. can be equally high or above those of control areas at sites with elevated $\mathrm{pCO}_{2}$ (Fabricius et al. 2014), supporting that the adults of these species may be resilient to increased $\mathrm{pCO}_{2}$. In our experiments, it appears that a higher energy requirement through enhanced metabolism also resulted in less energy available for gonad development. These results support our previous conclusion that the effects of OA on somatic fitness of Echinometra sp. A were smaller than those on reproduction and development (Uthicke et al. 2013), and the latter will have important implications for future survival of the species and population size maintenance.

Acknowledgments We are grateful for the assistance of M. Takahashi, F. Flores, and S. Noonan in the maintenance of the aquarium system. We are grateful for the statistical advice from Dr. M. Logan. The study was funded by the Australian Institute of Marine Science and conducted with the support of funding from the Australian Government's National Environmental Research Program and an Australian Research Council Discovery Grant.

Open Access This article is distributed under the terms of the Creative Commons Attribution License which permits any use, distribution, and reproduction in any medium, provided the original author(s) and the source are credited.

\section{References}

Albright R, Bland C, Gillette JP, Serafy E, Langdon C, Capo TR (2012) Juvenile growth of the tropical sea urchin Lytechinus variegatus exposed to near-future ocean acidification scenarios. J Exp Mar Biol Ecol 426:12-17

Anlauf H, D'Croz L, O'Dea A (2011) A corrosive concoction: The combined effects of ocean warming and acidification on the early growth of a stony coral are multiplicative. J Exp Mar Biol Ecol 397:13-20

Anthony KRN, Kline DI, Diaz-Pulido G, Dove S, Hoegh-Guldberg O (2008) Ocean acidification causes bleaching and productivity loss in coral reef builders. Proc Nat Acad Sci USA 105:17442

Arakaki Y, Uehara T, Fagoonee I (1998) Comparative studies of the genus Echinometra from Okinawa and Mauritius. Zool Sci 15:159-168

Arora VK, Scinocca JF, Boer GJ, Christian JR, Denman KL, Flato GM, Kharin VV, Lee WG, Merryfield WJ (2011) Carbon emission limits required to satisfy future representative concentration pathways of greenhouse gases. Geophys Res Lett 38:L05805

Brierley AS, Kingsford MJ (2009) Impacts of climate change on marine organisms and ecosystems. Cur Biol 19:602-614

Burnett L, Terwilliger N, Carroll A, Jorgensen D, Scholnick D (2002) Respiratory and acid-base physiology of the purple sea urchin, Strongylocentrotus purpuratus, during air exposure: Presence and function of a facultative lung. Biol Bull 203:42-50

Byrne M (1990) Annual reproductive cycles of the commercial sea urchin Paracentrotus lividus from an exposed intertidal and a sheltered subtidal habitat on the west coast of Ireland. Mar Biol 104:275-289

Byrne M (2011) Impact of ocean warming and ocean acidification on marine invertebrate life history stages: Vulnerabilities and potential for persistence in a changing ocean. Oceanogr Mar Biol Ann Rev 49:1-42

Byrne M (2012) Global change ecotoxicology: identification of early life history bottlenecks in marine invertebrates, variable species responses and variable experimental approaches. Mar Env Res 76:3-15

Byrne M, Przeslawski R (2013) Multistressor impacts of warming and acidification of the ocean on marine invertebrates' life histories. Integr Comp Biol 53:582-596

Byrne M, Andrew N, Worthington D, Brett P (1998) Reproduction in the diadematoid sea urchin Centrostephanus rodgersii in contrasting habitats along the coast of New South Wales, Australia. Mar Biol 132:305-318 
Byrne M, Lamare M, Winter D, Dworjanyn S, Uthicke S (2013) The stunting effect of a high $\mathrm{CO}_{2}$ ocean on calcification and development in sea urchin larvae, a synthesis from the tropics to the poles. Phil Trans R Soc Lond B Biol Sci 368:20120439

Byrne M, Ho M, Wong E, Soars NA, Selvakumaraswamy P, ShepardBrennand H, Dworjanyn SA, Davis AR (2011) Unshelled abalone and corrupted urchins: development of marine calcifiers in a changing ocean. Proc R Soc Lond B Biol Sci 278:2376-2383

Caldeira K, Wickett ME (2005) Ocean model predictions of chemistry changes from carbon dioxide emissions to the atmosphere and ocean. J Geophys Res 110:12

Carreiro-Silva M, McClanahan TR (2001) Echinoid bioerosion and herbivory on Kenyan coral reefs: the role of protection from fishing. J Exp Mar Biol Ecol 262:133-153

Catarino AI, Bauwens M, Dubois P (2012) Acid-base balance and metabolic response of the sea urchin Paracentrotus lividus to different seawater $\mathrm{pH}$ and temperatures. Env Sci Poll Res 19:2344-2353

Christensen AB, Nguyen HD, Byrne M (2011) Thermotolerance and the effects of hypercapnia on the metabolic rate of the ophiuroid Ophionereis schayeri: Inferences for survivorship in a changing ocean. J Exp Mar Biol Ecol 403:31-38

Collard M, Laitat K, Moulin L, Catarino AI, Grosjean P, Dubois P (2013) Buffer capacity of the coelomic fluid in echinoderms. Comp Biochem PhysPart A: Molecular \& Integrative Physiology 166:199-206

Collier CJ, Uthicke S, Waycott M (2012) Thermal tolerance of two seagrass species at contrasting light levels: Implications for future distribution in the Great Barrier Reef. Limnol Oceanogr 56:2200-2210

Collins M, Knutti R, Arblaster J, Dufresne J-L, Fichefet T, Friedlingstein P, Gao X, Gutowski W, Johns T, Krinner G, Shongwe M, Tebaldi C, Weaver A, Wehner M (2013) Long-term Climate Change: Projections, Commitments and Irreversibility. In: Stocker TF, Qin D, Plattner G-K, Tignor M, Allen SK, Boschung J, Nauels A, Xia Y, Bex V, Midgley PM (eds) Climate Change 2013: The Physical Science Basis Contribution of Working Group I to the Fifth Assessment Report of the Intergovernmental Panel on Climate Change. Cambridge University Press, Cambridge, United Kingdom and New York, NY, USA

Courtney T, Westfield I, Ries JB (2013) $\mathrm{CO}_{2}$-induced ocean acidification impairs calcification in the tropical urchin Echinometra viridis. J Exp Mar Biol Ecol 440:169-175

Dickson AG, Sabine CL, Christian JR (2007) Guide to best practices for ocean $\mathrm{CO} 2$ measurements. PICES special publication 3

Doney SC, Fabry VJ, Feely RA, Kleypas JA (2009) Ocean acidification: the other $\mathrm{CO}_{2}$ problem. Ann Rev Mar Sci 1:169-192

Downing N, El-Zahr CR (1987) Gut evacuation and filling rates in the rock-boring sea urchin, Echinometra mathaei. Bull Mar Sci 41:579-584

Dupont S, Dorey N, Stumpp M, Melzner F, Thorndyke M (2012) Long-term and trans-life-cycle effects of exposure to ocean acidification in the green sea urchin Strongylocentrotus droebachiensis. Mar Biol 160:835-1843

Evans TG, Chan F, Menge BA, Hofmann GE (2013) Transcriptomic responses to ocean acidification in larval sea urchins from a naturally variable $\mathrm{pH}$ environment. Mol Ecol 22:1609-1625

Fabricius KE, De'ath G, Noonan S, Uthicke S (2014) Ecological effects of ocean acidification and habitat complexity on reefassociated macroinvertebrate communities. Proc R Soc Lond B Biol Sci 281:20132479

Fabricius KE, Langdon C, Uthicke S, Humphrey C, Noonan S, De'ath G, Okazaki R, Muehllehner N, Glas MS, Lough JM (2011) Losers and winners in coral reefs acclimatized to elevated carbon dioxide concentrations. Nat Clim Change 1:165-169
Garrido CL, Barber BJ (2001) Effects of temperature and food ration on gonad growth and oogenesis of the green sea urchin, Strongylocentrotus droebachiensis. Mar Biol 138:447-456

Hall-Spencer JM, Rodolfo-Metalpa R, Martin S, Ransome E, Fine M, Turner SM, Rowley SJ, Tedesco D, Buia MC (2008) Volcanic carbon dioxide vents show ecosystem effects of ocean acidification. Nature 454:96-99

Hobday AJ, Lough JM (2011) Projected climate change in Australian marine and freshwater environments. Mar Freshw Res 62:1000-1014

Hoegh-Guldberg O (1999) Climate change, coral bleaching and the future of the world's coral reefs. Mar Freshw Res 50:839-866

Holtmann WC, Stumpp M, Gutowska MA, Syré S, Himmerkus N, Melzner F, Bleich M (2013) Maintenance of coelomic fluid pH in sea urchins exposed to elevated $\mathrm{CO}_{2}$ : the role of body cavity epithelia and stereom dissolution. Mar Biol 160:2631-2645

Kurihara H, Shirayama Y (2004) Effects of increased atmospheric $\mathrm{CO}_{2}$ on sea urchin early development. Mar Ecol Prog Ser 274:161-169

Kurihara H, Yin R, Nishihara GN, Soyano K, Ishimatsu A (2013) Effect of ocean acidification on growth, gonad development and physiology of the sea urchin Hemicentrotus pulcherrimus. Aquatic Biol 18:281-292

Lamare M, Pecorino D, Hardy N, Liddy M, Byrne M, Uthicke S (2014) The thermal tolerance of crown-of-thorns (Acanthaster planci) embryos and bipinnaria larvae: implications for spatial and temporal variation in adult populations. Coral Reefs 33:207-219

Landry C, Geyer LB, Arakaki Y, Uehara T, Palumbi SR (2003) Recent speciation in the Indo-West Pacific: rapid evolution of gamete recognition and sperm morphology in cryptic species of sea urchin. Proc R Soc Lond B Biol Sci 270:1839-1847

Langenbuch M, Pörtner HO (2002) Changes in metabolic rate and N excretion in the marine invertebrate Sipunculus nudus under conditions of environmental hypercapnia. J Exp Biol 205:1153

McClanahan TR, Muthiga NA (2007) Ecology of Echinometra. In: Lawrence JM (ed) Developments in Aquaculture and Fisheries Science 37:297-317

McClanahan TR, Kamukuru AT, Muthiga NA, Yebio MG, Obura D (1996) Effect of sea urchin reductions on algae, coral, and fish populations. Conserv Biol 10:136-154

McElroy DJ, Nguyen HD, Byrne M (2012) Respiratory response of the intertidal seastar Parvulastra exigua to contemporary and near-future pulses of warming and hypercapnia. J Exp Mar Biol Ecol 416:1-7

Meinshausen M, Smith SJ, Calvin K, Daniel JS, Kainuma MLT, Lamarque J, Matsumoto K, Montzka S, Raper SCB, Riahi K (2011) The RCP greenhouse gas concentrations and their extensions from 1765 to 2300. Clim Change 109:213-241

Miles H, Widdicombe S, Spicer JI, Hall-Spencer J (2007) Effects of anthropogenic seawater acidification on acid-base balance in the sea urchin Psammechinus miliaris. Mar Poll Bull 54:89-96

Moss RH, Edmonds JA, Hibbard KA, Manning MR, Rose SK, van Vuuren DP, Carter TR, Emori S, Kainuma M, Kram T (2010) The next generation of scenarios for climate change research and assessment. Nature 463:747-756

Muthiga N, Jaccarini V (2005) Effects of seasonality and population density on the reproduction of the Indo-Pacific echinoid Echinometra mathaei in Kenyan coral reef lagoons. Mar Biol 146:445-453

Nguyen KDT, Morley SA, Lai CH, Clark MS, Tan KS, Bates AE, Peck LS (2009) Upper temperature limits of tropical marine ectotherms: global warming implications. PLoS ONE 6:e29340

Otero-Villanueva MM, Kelly MS, Burnell G (2004) How diet influences energy partitioning in the regular echinoid Psammechinus miliaris; constructing an energy budget. J Exp Mar Biol Ecol 304:159-181 
Pörtner HO (2008) Ecosystem effects of ocean acidification in times of ocean warming: a physiologist's view. Mar Ecol Prog Ser 373:203-217

Pörtner HO, Langenbuch M, Reipschläger A (2004) Biological impact of elevated ocean $\mathrm{CO}_{2}$ concentrations: lessons from animal physiology and earth history. J Oceanogr 60:705-718

Development Core Team R (2012) R: A language and environment for statistical computing. R Foundation for Statistical Computing, Vienna, Austria

Rahman MS, Rahman SM, Uehara T (2007) Effects of temperature on early development of the sea urchin Echinometra mathaei from the intertidal reef of Okinawa Island, Japan. Galaxea 9:35-48

Reynaud S, Leclercq N, Romaine-Lioud S, Ferrier-Pagés C, Jaubert J, Gattuso JP (2003) Interacting effects of $\mathrm{CO}_{2}$ partial pressure and temperature on photosynthesis and calcification in a scleractinian coral. Glob Chang Biol 9:1660-1668

Ries JB, Cohen AL, McCorkle DC (2009) Marine calcifiers exhibit mixed responses to $\mathrm{CO}_{2}$-induced ocean acidification. Geology 37:1131

Rupp JH (1973) Effects of temperature on fertilization and early cleavage of some tropical echinoderms, with emphasis on Echinometra mathaei. Mar Biol 23:183-189

Ryle VD, Müller HR, Gentien P (1981) Automated analysis of nutrients in tropical seawater. AIMS Oceanography Series OS82-2, AIMS, Townsville, pp 24

Sabine CL, Feely RA, Gruber N, Key RM, Lee K, Bullister L, Wanninkhof R, Wong CS, Wallace DWR, Tilbrook B (2004) The oceanic sink for anthropogenic $\mathrm{CO}_{2}$. Science 305:367-371

Sheppard Brennand H, Soars N, Dworjanyn SA, Davis AR, Byrne M (2010) Impact of ocean warming and ocean acidification on larval development and calcification in the sea urchin Tripneustes gratilla. PLoS ONE 5:e11372

Sheridan JA, Bickford D (2011) Shrinking body size as an ecological response to climate change. Nat Clim Chang 1:401-406

Shirayama Y, Thornton H (2005) Effect of increased atmospheric CO2 on shallow water marine benthos J Geophys Res110:C09S08

Shpigel M, McBride SC, Marciano S, Lupatsch I (2004) The effect of photoperiod and temperature on the reproduction of European sea urchin Paracentrotus lividus. Aquaculture 232:343-355
Sikes CS, Okazaki K, Fink RD (1981) Respiratory $\mathrm{CO}_{2}$ and the supply of inorganic carbon for calcification of sea urchin embryos. Comp Biochem Physiol A Physiol 70:285-291

Spicer JI, Widdicombe S, Needham HR, Berge JA (2011) Impact of $\mathrm{CO}_{2}$-acidified seawater on the extracellular acid-base balance of the northern sea urchin Strongylocentrotus droebachiensis. J Exp Mar Biol Ecol 407:19-25

Stumpp M, Hu MY, Melzner F, Gutowska MA, Dorey N, Himmerkus N, Holtmann WC, Dupont ST, Thorndyke MC, Bleich M (2012a) Acidified seawater impacts sea urchin larvae $\mathrm{pH}$ regulatory systems relevant for calcification. Proc Nat Acad Sci USA 109:18192-18197

Stumpp M, Truebenbach K, Brennecke D, Hu MY, Melzner F (2012b) Resource allocation and extracellular acid-base status in the sea urchin Strongylocentrotus droebachiensis in response to $\mathrm{CO}_{2}$ induced seawater acidification. Aquat Toxicol 110:194-207

Tsuchiya M, Yanagiya K, Nishihira M (1987) Mass mortality of the sea urchin Echinometra mathaei (Blainville) caused by high water temperature on the reef flats in Okinawa, Japan. Galaxea Nishihara 6:375-385

Ulbricht RJ, Pritchard AW (1972) Effect of temperature on the metabolic rate of sea urchins. Biol Bull 142:178-185

Uthicke S (2001) Nutrient regeneration by abundant coral reef holothurians. J Exp Mar Biol Ecol 265:153-170

Uthicke S, Soars N, Foo S, Byrne M (2013) Effects of elevated $p \mathrm{CO}_{2}$ and the effect of parent acclimation on development in the tropical Pacific sea urchin Echinometra mathaei. Mar Biol 160:1913-1926

Wood HL, Spicer JI, Widdicombe S (2008) Ocean acidification may increase calcification rates, but at a cost. Proc R Soc Lond B Biol Sci 275:1767-1773

Wood HL, Spicer JI, Lowe DM, Widdicombe S (2010) Interaction of ocean acidification and temperature; the high cost of survival in the brittlestar Ophiura ophiura. Mar Biol 157:2001-2013

Wood HL, Spicer JI, Kendall MA, Lowe DM, Widdicombe S (2011) Ocean warming and acidification; implications for the Arctic brittlestar Ophiocten sericeum. Polar Biol 34:1033-1044 